Iwona Żuraszek-Ryś

Uniwersytet Zielonogórski

\title{
Czy Łużyce są nam bliskie? O nazwach z członami Łużyce, tużycki i Łużyczanin / Łü̇yczanka we współczesnej polszczyźnie
}

Łużyce stanowią fenomen w dziejach Europy. Ich mieszkańcy przez wiele stuleci dzielnie zmagali się z żywiołem germańskim, zachowując swoją tożsamość. Ta postawa budziła i nadal budzi nasz podziw. Czy to uznanie ma odzwierciedlenie w języku, np. w nazwach własnych funkcjonujących we współczesnej polszczyźnie? Przedmiot niniejszych rozważań będą stanowić onimy z członami Łużyce, tużycki, Łużyczanin / Łużyczanka wyekscerpowane z Internetu przy pomocy wyszukiwarki Google ${ }^{1}$.

\section{1. Łużyce}

Łużyce to „niem. kraina hist. w pd.-wsch. części Niemiec, między Nysą Łużycką a Łabą; dzielą się na Ł. Dolne (część pn.), z gł. m. Chociebuż (Cottbus) i Ł. Górne (pd.), z gł. m. Budziszyn (Bautzen)"2. Spośród ogólnych słowników języka polskiego po raz pierwszy leksem Łużyce notuje Słownik języka polskiego Samuela Bogumiła Lindego i w tym źródle pojawia się on w formie zlatynizowanej: „Luzacya (Boh. Luzice; Sorab. 1. Luzizy; 2. Laufinska, cf. luža kałuża); dzieli się na dolną i górną"’.

We współczesnej polszczyźnie funkcjonuje wiele onimów motywowanych Łużycami. Analiza zgromadzonego materiału pozwoliła dostrzec różnorodność typów, w których ta nazwa się ujawniła:

${ }^{1} \mathrm{~W}$ artykule ze względu na bogactwo materiału zostaną przedstawione tylko przykłady ilustrujące omawiane typy.

${ }^{2}$ Nowa encyklopedia powszechna PWN, t. 5, Warszawa 2004, s. 216.

${ }^{3}$ S.B. Linde, Stownik języka polskiego, t. II, Lwów 1855, s. 684. 
a) toponimy: Łużyce Dolne i Łużyce Górne (nazwy te mają postać złożenia z członem dyferencyjnym, służącym odróżnieniu tych dwóch krain. Jak pisał Franciszek Mincer: „Nazwą Łużyc przez całe wieki nazywano tylko terytorium dzisiejszych Łużyc Dolnych, których głównym ośrodkiem jest Chociebuż. Dopiero w XV wieku nazwę Łużyc rozciągnięto również na Milsko (ziemię dawnego plemienia Milczan), które od tego czasu zaczęto nazywać Łużycami Górnymi"4. Istnienie podziału Łużyc na dwie części jest więc efektem dawnych procesów historyczno-politycznych);

b) chrematonimy 5 :

- pełniące głównie funkcję lokalizacyjną (przywołanie w nazwie $Ł u \dot{z y c}$ wskazuje na obszar działalności):

- nazwa hotelu Łużyce w Lubaniu;

- nazwa klubu sportowego Łużyce w Lubaniu;

- nazwy organizacji, np.: Polski Związek Hodowców Gołębi Pocztowych Oddział Lubań-Łużyce Sekcja Chmieleń, Rodzinny Ogród Działkowy „Łużyce” w Zgorzelcu;

- nazwa pociągu Łużyce relacji Węgliniec - Kraków6;

- nazwy przedsiębiorstw, zakładów, np.: Łużyce Beton Sp. z o.o., Spółdzielnia Pracy Łużyce w Zgorzelcu;

- pełniące także inne funkcje:

- nazwa formacji wojskowej: Baza Lotnicza Armii Krajowej „Łużyce” (pojawienie się $\mathrm{w}$ tej nazwie określenia Łużyce było podyktowane względami asocjacyjnymi - odwołanie do historii narodu, który przez wiele stuleci zmagał się z jarzmem niemieckim stanowiło przykład i zachętę do podjęcia dalszej walki);

- nazwa telewizji Łużyce (odwołanie w nazwie do Łużyc wskazuje na zasięg upowszechnienia, a także podejmowaną tematykę);

${ }^{4}$ F. Mincer, Ekspansja brandenburska na Łużcach do 1815 roku, w: Łużyce w nowożytnych i najnowszych dziejach Europy Środkowej, red. T. Jaworski i M. Ostrowski, Zielona Góra 1995, s. 53.

${ }^{5}$ Zakres tej kategorii onimicznej nie jest do końca ustalony. W onomastyce polskiej przyjmuje się tzw. stanowisko minimalistyczne (zawężające przedmiot badań chrematonimii tylko do niektórych materialnych wytworów ręki ludzkiej, przemysłowych lub rękodzielniczych) lub maksymalistyczne [zob. np. E. Breza, Nazwy obiektów i instytucji zwiąanych z nowoczesną cywilizacja (chrematonimy), w: Polskie nazwy własne, red. E. Rzetelska-Feleszko, Warszawa-Kraków 1998, s. 343-361; C. Kosyl, Chrematonimy, w: Współczesny język polski, red. J. Bartmiński, Wrocław 1993, s. 440-444]. W niniejszym opracowaniu przyjęto stanowisko maksymalistyczne, uznając za chrematonimy określenia właściwie prawie wszystkich wytworów rąk ludzkich, które pisane są wielką literą, a więc także np. nazwy czasopism i dzienników, tytuły publikacji czy nazwy organizacji politycznych i społecznych.

${ }^{6} \mathrm{Na}$ funkcję lokalizacyjną nazw pociągów jako środków transportu kursujących na określonej trasie wskazywał M. Buczyński w: Nazwy własne pojazdów komunikacyjnych w Polsce, „Zeszyty Naukowe Uniwersytetu Gdańskiego. Prace Językoznawcze” 1982, 8, s. 181-187. 
- nazwy czasopism, np.: „Gazeta Wojewódzka Nowe Łużyce”, „Łużyce” (odwołanie w nazwie do $Ł u \dot{z} y c$ wskazuje na zasięg upowszechnienia, a także podejmowaną tematykę; są to czasopisma o charakterze lokalnym);

- nazwy organizacji, np.: Fundacja Społeczna „Łużyce” w Trójcy, Stowarzyszenie Miłośników Górnych Łużyc w Lubaniu (odwołanie w nazwach tych stowarzyszeń do Łużyc nie ma jedynie charakteru lokalizacyjnego, można wskazać także inne względy);

- tytuły publikacji książkowych, np.: J. Chociszewski, Bojomir, czyli zaprowadzenie chrześcijaństwa w Łuzycach: powieść dla ludu polskiego i doroślejszej młodzieży (e-book); Górne Łużyce na przestrzeni wieków, red. J. Maroń, Ł. Tekiela, Lubań 2007; K. Kaczmarek, W bojach przez Łużyce: Na drezdeńskim kierunku operacyjnym, Warszawa 1965; T. Kowalczyk, Kościót katolicki na Łużycach Górnych w latach 1919-1990, Lublin 1999; Łużyce w nowożytnych i najnowszych dziejach Europy Środkowej, red. T. Jaworski, M. Ostrowski, Zielona Góra 1995; R. Primke, M. Szczerepa, W. Szczerepa, Wojny husyckie na Ślasku, Łużycach i Pomorzu. Wyprawy - bitwy - postacie, Kraków 2007; D. Silwanowicz, Lubuskie. Między Śląskiem a Łużycami, Gdynia 2012; J. Skowroński, Tajemnice Lubania. Łużyce nieznane, Warszawa 2010; J. Szczepankiewicz-Battek, Łużyce-przestrzeń dyslokacji kultur narodowych, religijnych, Słupsk 2005; Ł. Tekiela, Wojna trzydziestoletnia na Górnych Łużycach. Aspekty militarne, Racibórz 2010; A. Woźny, Łużyce w planie dywersji polskiego wywiadu wojskowego w latach 1931-1939, Opole 2010; A. Zieliński, Podróże Polaków na Łużyce w XIX wieku, Wrocław 1975 (książki, w których tytule pojawia się analizowana forma, wydawane są w całej Polsce, może to świadczyć o szerokim zainteresowaniu problematyką łużycką; tytuły są swoistą etykietką, za pomocą której identyfikuje się tekst: użycie nazwy Łużyce było podyktowane z jednej strony względami charakteryzująco-informacyjnymi, wskazuje bowiem na zawartość treściową publikacji, odnosi się do umiejscowienia konkretnego wydarzenia w czasie i przestrzeni, ale z drugiej strony także względami konotacyjnymi - np. wywołanie skojarzeń z kulturą, historią regionu $^{7}$ ).

Jak można zauważyć, użycie członu Łużyce w chrematonimach było podyktowane głównie względami lokalizacyjnymi ${ }^{8}$, wskazywało bowiem np.

${ }^{7}$ Magdalena Graf w swoim artykule Funkcja lokalizacyjna nazewnictwa literackiego. Próba nowego spojrzenia zwracała uwagę, że nazwy w dziele literackim mogą odgrywać nie tylko rolę lokalizacyjną, ale także otwierać tekst na szersze poziomy interpretacyjne: M. Graf, Funkcja lokalizacyjna nazewnictwa literackiego. Próba nowego spojrzenia, w: Nazwy mówia, red. M. Pająkowska-Kensik i M. Czachorowska, Bydgoszcz 2004, s. 169-177.

${ }^{8}$ Podstawową funkcją pełnioną przez każdą nazwę własną jest funkcja identyfikacyjna. Wyraża się ona w tym, że nazwa wskazuje na konkretny obiekt. W związku z jej obligatoryjnym 
na obszar działalności spółek, zakładów, stowarzyszeń. Wiele z nich funkcjonuje przecież w powiatach: bogatyńskim, gubińskim, lubańskim, zgorzeleckim i żarskim, a więc na terenie zarówno historycznych Łużyc Dolnych, jak i Łużyc Górnych. Wśród nazw pojawiły się jednak i onimy o charakterze pamiątkowym (np. Baza Lotnicza Armii Krajowej „Łużyce”). Głównym powodem odwołania do Łużyc (a właściwie do mieszkańców tego regionu) były dodatkowe cechy znaczeniowe i emocjonalne, które się z nimi kojarzą. Szczególną pozycję wśród analizowanego materiału zajmują tytuły utworów literackich i prac naukowych, w których użycie nazwy Łużyce było motywowane zarówno względami charakteryzująco-informacyjnymi, jak i asocjacyjnymi.

\section{2. Łużycki}

Podobnie jak w przypadku $\measuredangle u z \dot{y} y$, tak i leksem tużycki po raz pierwszy w słowniku notuje S.B. Linde 9 . Łużycki jest to derywat powstały od onimu Łużyce. Może mieć znaczenie toponimiczne (dotyczące określonego obszaru) oraz etnonimiczne (związane z mieszkańcami Łużyc). Jak pisała Bożena Itoya:

może dotyczyć także zjawisk charakterystycznych dla całego regionu (Łużyc „słowiańskich” i ,niemieckich”), jak również, szczególnie w Polsce, tak zwanych Łużyc Wschodnich, terenu leżącego na terenie Polski, niezamieszkanego przez Łużyczan. Określenie łużycki posiada w języku polskim rozmaite znaczenia: 'dotyczący regionu historycznych Łużyc Wschodnich na terenie RP', 'dotyczący Słowian zamieszkujących w regionie Łużyce na terenie RFN', 'dotyczący regionu Łużyce na terenie RFN', ich mieszanie prowadzi czasem do nieścisłości i błędów merytorycznych ${ }^{10}$.

Łużycki, podobnie jak i wcześniej Łużyce, ujawnił się w kilku typach nazw własnych:

charakterem pominięto w poszczególnych opisach informacje o tej funkcji. Zwrócono jednak uwagę na inne funkcje pełnione przez analizowane onimy (np. lokalizacyjną, konotacyjną).

${ }^{9}$ S.B. Linde, op. cit., s. 684: Luzacki, Sorab. 1. lužiski. W tzw. słowniku wileńskim pojawia się już forma łużycki: p. z Łużyc (prowincji na Szląsku), do Łużyc należący (Słownik języka polskiego, red. A. Zdanowicz i in., wydany staraniem i kosztem Orgelbranda, t. I, Wilno 1861, s. 615).

${ }^{10}$ B. Itoya, Jak mówić o Łużycach w języku polskim? Analiza terminów Łużyczanin / Serbolużyczanin / Serb Łużycki, język tużycki / język serbołu̇ycki / języki łużyckie / łużycczyzna oraz derywatu tu̇̇ycki / serbołużycki na tle porównawczym (wybrane języki europejskie), „Pro Lusatia” 2011, t. 10, s. 64. 
a) antroponimach:

- nazwisko Łużycki (w Słowniku nazwisk współcześnie w Polsce używanych Kazimierza Rymuta ${ }^{11}$ odnotowano tylko jedenaście poświadczeń tego nazwiska w Polsce: dwa w woj. warszawskim, siedem w woj. bielskim i dwa w woj. lubelskim; jest to przykład nazwiska utworzonego od toponimu za pomocą formantu -cki);

- etnonim Serb Łużycki (inne określenie mieszkańca Łużyc). Jak pisała B. Itoya:

W odniesieniu do Łużyczan nie powinny być stosowane polskie terminy: Serbowie, Serbowie Łużyccy, ponieważ są one mylące. Większość użytkowników języka polskiego, a nawet slawistów, nie łączy Serba z nikim innym niż ze Słowianinem z Serbii. Ponadto o istnieniu Łużyczan wie stosunkowo niewielu użytkowników języka polskiego, w świadomości laika Serb Łużycki może stać się kuzynem Serba z Serbii lub byłej Jugosławii, reprezentantem mniejszości serbskiej poza Serbią ${ }^{12}$.

Ta opinia wydaje mi się jak najbardziej słuszna;

b) nazwach miejscowych:

- Dąbrowa Łużycka (wieś położona w powiecie żarskim, w gminie Przewóz: „Dubrau 1787 Z VII 93; Dubrau, łuż. Dubrawa 1845 K 107; Eichenwald, Dubrawa 1941 Wrzosek 37; Eichenwald - Dąbrowa Łużycka, -y -kiej, dąbrowski 1947 MPol XXV nr 124; Dąbrowa Łużycka, -wy-kiej 1980 WUN I 306. - Dawna n. łuż. Dubrawa od ap. dubrawa 'dąbrowa'. Obecna n. urzędowo wprowadzona po 1945 r." ${ }^{13}$ );

- Kamienica nad Nysą Łużycką (wieś położona w powiecie żarskim, w gminie Trzebiel: „Kemnitz 1928 Muka III 149; Kemnitz - Kamienica n/Nysa, wzgl. Nisa Łużycką, -cy, kamienicki 1947 MPol XXVI nr 37; Kamienica n. Nysa 1952 UW 224; Kamienica nad Nysą Łużycka, -cy nad Nysa Łużycka 1981 WUN II 17; dłuż.: kaḿeńca, kaḿeńcański Muka III 149. - Od łuż. kamjeńc 'mały kamień', pol. kamieniec 'kamieniste pole' SW II 220 lub od kamienica. N. zniemczona jako Kemnitz. Określenie lokalizujące nad Nysa Łużycka od n. rzeki”"14);

- Lipa Łużycka (wieś położona w powiecie żarskim, w gminie Przewóz: „,pago Leippe 1679, Leipach 1687/88 J III 289, 686; Leipa-Leippa 1896 D 174; Selingersruh, Lipa; 1941 Wrzosek 38; Selingersruh-Lipa Łużycka, -py -kiej,

${ }^{11}$ K. Rymut, Stownik nazwisk współcześnie w Polsce używanych, t. VI, Kraków 1993, s. 82 .

12 B. Itoya, op.cit., s. 63.

13 Nazwy miejscowe Polski. Historia. Pochodzenie. Zmiany, red. K. Rymut, t. II, Kraków 1997, s. 289.

${ }^{14}$ Ibidem, t. IV, Kraków 2001, s. 285. 
lipski 1947 MPol XXVI nr 37; Lipa Łużycka - Selingersruh (Leippa), wś 1951 Rosp 162; Lipa Łużcka 1967 SM 596 - Dawniej n. niem. Leippe = pol. Lipa. Niem. n. Selingersruh została nadana przez władze hitlerowskie. Po II wojnie urzędowo wprowadzono pol. n. Lipa Łużycka" ${ }^{15}$ );

- Lipinki Łużyckie (wieś położona w powiecie żarskim, siedziba gminy: „Lyndenrade 1381, Lindenrode początek XVI w. Le II 369; Linderode 1563 CdSil XXXII 13; pago Linderode 1687/88 J III 692; Lindroz, Linderode 1881 SG V 239; Linderode 1928 Muka III 158; Linderode - Lipinki Lużyckie, -nek -ich, lipinecki 1947 MPol XXVI nr 37; Lipinki Łużyckie, -nek-kich 1981 WUN II 300; dłuż. Lindroz Le II 369, przym. Lindrojski Muka III 158. - Od niem. Linde 'lipa' i roden 'karczować, trzebić'. Nazwa Lipinki z członem odróżniającym Łużyckie (osada leży na terenie dawnych Łużyc) została wprowadzona urzędowo po 1945 r."16);

- Nawojów Łużycki (wieś położona w powiecie lubańskim, w gminie Lubań: „Zabuloth (1233) XVIII Sur II 33; in Hugisdorfh 1287, Crass Hugonis (!) 1291 Reg nr 2052, 2197; Hawgisdorff, Haugisdorff (1346), Hugisdorf 1391 KOL 57; Huxdorff 1391 CdL III 177; zu Haugsdorf 1426 CdL II/1, 311; von Hawgesdorff 1431 CdL II/2, 214; Hugisdorf 1438, Hugszdorff 1454 Cdl IV 24, 882; Haugsdorff 1454, Hausdorf 1507, Haugsdorff 1599 KOL 57; Haugsdorf, Ober-Lausitzisch, Sächsisch, auch Hausdorf 1845 K 211; Sächsisch Haugsdorf 1941 Wrzosek 34; Sächsisch Haugsdorf - Nawojów Łużycki, -owa, -ego, nawojowski 1947 MPol XXVI nr 37; Nawojów Łużycki, -jowa -kiego 1981 WUN II 521 - najstarszy zapis Zabuloth niejasny; może jest to n. Zabłocie (częsta), od ap. zabłocie 'miejsce położone za błotem'. Oboczna n. niem. Hugisdorf od n. os. Hugo, Haug (: Hugiwulf) Gott $264+$ Dorf 'wieś'. Od XIX w. n. z członem Sächsisch 'saksoński' (Łużyce należały wówczas do Saksonii) oraz Ober-Lausitzisch 'górnołużycki'. Obecną n. wprowadzono urzędowo po 1945 r., z członem Łużycki w celu odróżnienia od Nawojowa Ślaskiego" ${ }^{17}$ );

- Osiek Łużycki - wieś położona w powiecie zgorzeleckim, w gminie Zgorzelec: „Stara n. głuż. Wósyk // Wosyk $\leftarrow$ stsłow. osěkb 'wyrąb’ Muka A. 368. Po 1945 r. Komisja URM ustaliła n. Osiek Łużycki nawiązując do hist. zapisów niem. Wendisch 'łużycki'"'18).

Jak pokazują powyższe zapisy, wymienione nazwy zostały wprowadzone urzędowo po zakończeniu II wojny światowej. Użycie w nich przydawki o charakterze etnicznym było podyktowane z jednej strony względami lokalizacyj-

${ }^{15}$ Ibidem, t. VI, Kraków 2005, s. 125.

16 Ibidem, s. 134.

17 Ibidem, t. VII, Kraków 2007, s. 362.

${ }_{18}$ Stownik etymologiczny nazw geograficznych Śląska, red. S. Sochacka, t. 9, Opole 1999, s. 99 . 
nymi, wskazującymi na położenie tych miejscowości na terenie historycznych Łużyc, z drugiej jednak strony nie można wykluczyć, jak twierdzą zresztą niektórzy historycy, względów propagandowych. Na tego typu motywy w nadawaniu nazw z członem etnicznym wskazuje też Monika Choroś w artykule $O$ kilku ślaskich nazwach komponowanych z czlonem etnicznym: „nazwy w formie zestawień z przydawką o charakterze etnicznym [...] są świadectwem manipulacji i instrumentalizacji, wykorzystywania dla osiągnięcia aktualnych celów politycznych i społecznych. Dziś nie wskazują już na przynależność narodową ich mieszkańców, lecz są świadkiem skomplikowanej i różnorodnej historii tego regionu" ${ }^{\prime 19}$. Władzy w czasach powojennych mogło zależeć na wyeksponowaniu historycznej przeszłości tych ziem, na zwróceniu uwagi na ich pierwotną przynależność do Łużyc, zanim te tereny zasiedliły plemiona germańskie. Nadanie nazw odpowiednio uzasadnionych, symbolizujących słowiańskość mogło być ważnym elementem w oswajaniu obcej rzeczywistości. Człowiek w przestrzeni nieznanej czuje się przecież zagubiony, brak mu poczucia bezpieczeństwa, stabilności. Onimy z członem lużycki miały więc dać nowym osadnikom poczucie komfortu i zapewnić, że ziemie, na które przybyli, nie są obce, gdyż przed wiekami były zasiedlone przez Słowian. Chodziło więc również o łatwiejszą integrację, szybsze przystosowanie do nowych warunków życia. W moim przekonaniu w repolonizowaniu omawianych nazw główną rolę odegrał jednak nie czynnik propagandowy, ale faktyczny, historycznie uzasadniony związek tych nazw z Łużycami.

Do innych typów nazw własnych należą:

c) nazwy terenowe: Śląsko-Łużycka Nizina, Wzniesienia Łużyckie (użycie członu łużycki w tego typu nazwach jest motywowane głównie względami lokalizacyjnymi, wskazuje na określone położenie geograficzne tych krain);

d) hydronimy: Nysa Łużycka (nazwa ta ma postać złożenia z członem dyferencyjnym w stosunku do pozostałych dwóch nazw rzek z tą samą podstawą Nysa Kłodzka i Nysa Szalona; użycie członu tużycki było podyktowane, oprócz względów identyfikacyjnych, także i lokalizacyjnymi, wskazuje również na położenie geograficzne tej rzeki);

e) urbonimy: ul. Łużycka, os. Łużyckie, pl. Łużycki (jak pisała Kwiryna Handke: „Rozwój nazewnictwa miejskiego w XIX i XX w. przyniósł daleko posuniętą unifikację nazw w różnych miastach polskich, przy równoczesnym

19 Ta wypowiedź odnosi się do nazw śląskich, w których można wyodrębnić człon o charakterze etnicznym. Autorka zaznacza jednak, że w badanych przez nią nazwach forma tużycki pojawia się zawsze na określenie miejscowości położonej na historycznych Łużycach (M. Choroś, O kilku śląskich nazwach komponowanych z członem etnicznym, w: Region w świetle nazw miejscowych, red. S. Gajda, Opole 2007, s. 111). 
zacieraniu się cech odróżniających poszczególne organizmy miejskie"20. Przejawem tych tendencji jest tworzenie nazw powielających dawne modele oraz preferowanie nazw pamiątkowych. Przytoczone powyżej urbonimy zostały utworzone po II wojnie światowej według pewnych schematów. Wiele z nich pochodzi jednak z miast leżących na terenie historycznych Łużyc albo z nimi sąsiadujących. Nie są to więc w moim przekonaniu urbonimy całkowicie pozbawione realnej motywacji. W stosunku do nich można mówić także o ich terenowym uzasadnieniu);

f) chrematonimy:

- pełniące głównie funkcję lokalizacyjną:

- nazwy aptek, np.: Łużycka w Tuplicach, Zgorzelcu, Żarach;

- nazwa banku: Łużycki Bank;

- nazwy hoteli i moteli, np.: Motel Łużycki w Lubaniu, Hotel Łużycki w Żarach;

- nazwy instytucji, ośrodków, stowarzyszeń, np.: Górnołużyckie Stowarzyszenie Pszczelarzy, Impet - Łużycka Giełda Nieruchomości, Łużycka Izba Gospodarcza;

- nazwy inwestycji, np.: Łużycka Office Park w Gdyni, Pasaż Łużycki w Krakowie (obie inwestycje znajdują się przy ul. Łużyckiej);

- nazwy jednostek wojskowych i grup historycznych: Łużycka Brygada Wojsk Ochrony Pogranicza, Łużycka Drużyna;

- nazwy placówek medycznych: Łużyckie Centrum Medyczne w Lubaniu oraz w Żarach;

- nazwy przedsiębiorstw, zakładów, np.: Łużycka Kopalnia Bazaltu „Księginki”, Łużyckie Praliny, Tartak Łużycki;

- nazwy sklepów, galerii handlowych, np.: Galeria Łużycka w Gubinie i w Lubaniu;

- pełniące także inne funkcje:

- nazwa jednostki wojskowej: Łużycka Dywizja Desantowa (nazwa o charakterze pamiątkowym);

- nazwy imprez kulturalnych, sportowych, biznesowych, np.: Biesiada Łużycka, Dni Łużyckie, Jarmark Łużycki, Łużyckie Wędrówki (człon łużycki w przywołanych nazwach wskazuje z jednej strony na miejsce organizacji imprez, a z drugiej również na charakter podejmowanych inicjatyw);

- nazwy instytucji, ośrodków, stowarzyszeń, np.: Łużyckie Stowarzyszenie Wszechstronnego Wspierania Kultury, Ośrodek Kultury Łużyckiej / Skansen Łużycki (człon łużycki w przywołanych nazwach wskazuje z jednej

${ }^{20}$ K. Handke, Nazewnictwo miejskie, w: Polskie nazwy własne, red. E. Rzetelska-Feleszko, Warszawa-Kraków 1998, s. 298. 
strony na obszar działalności poszczególnych instytucji, ale z drugiej przynosi dodatkowe treści konotacyjne, np. o charakterze kulturowo-historycznym. Zresztą w wielu statutach znajdują się informacje o tym, że celem tych instytucji jest pielęgnowanie tradycji regionalnych. Tego typu sformułowania świadczą o wytworzeniu więzi z regionem i zaawansowaniu procesów tożsamościowych);

- nazwy lokali gastronomicznych, np.: Karczma Łużycka (użycie członu tużycki $\mathrm{w}$ tej nazwie nie jest motywowane jedynie względami lokalizacyjnymi, ale przynosi także dodatkowe informacje, związane np. z rodzajem kuchni);

- nazwy muzeów: Muzeum Łużyckie, Muzeum Pogranicza Śląsko-Łużyckiego (człon łużycki w przywołanych wyżej nazwach wskazuje na obszar działalności tych instytucji, a także prezentowaną przez nich tematykę i charakter podejmowanych działań);

- nazwy szkół, np.: Gimnazjum Łużyckie, Łużycka Wyższa Szkoła Humanistyczna (człon $\nmid u \dot{y y c k i}$ w przywołanych wyżej nazwach wskazuje na obszar działalności tych placówek, a także ich charakter);

- tytuły czasopism, dzienników, serii wydawniczych, np.: „Gazeta Łużycka”, „Łużycki Magazyn Gospodarczy”, Łużyckie Zeszyty Naukowe, „Szkice Górnołużyckie”, „Zeszyty Łużyckie” (człon łużycki w tych nazwach wskazuje z jednej strony na zasięg upowszechnienia, zwłaszcza w odniesieniu do tytułów o charakterze lokalnym, a także podejmowaną tematykę; wśród tej grupy szczególną uwagę należy zwrócić na publikacje ukazujące się poza historycznymi Łużycami, np. „Zeszyty Łużyckie”, gdyż ich zasięg oraz prezentowane w nich treści są znacznie szersze);

- tytuły publikacji książkowych, np.: A. Cerny, Istoty mityczne Serbów tużyckich, Warszawa 1901; T. Jaworski, Mobilność społeczeństwa wielokulturowego na pograniczu śląsko-tużyckim od XVI do XVIII w., Zielona Góra 2007; Ziemia Łużycka. Miniprzewodnik, Gliwice 2012 (e-book) (użycie członu łużycki w tytułach tych publikacji było podyktowane głównie względami charakteryzująco-informacyjnymi, odnosi się bowiem do umiejscowienia konkretnego wydarzenia w czasie i przestrzeni, wskazuje na zawartość treściową publikacji, ale należy także pamiętać o dodatkowych względach konotacyjnych - o czym już zresztą była mowa wyżej, w komentarzu do nazw tytułów publikacji książkowych z członem Łużyce).

Najwięcej nazw z członem łużycki odnotowałam wśród chrematonimów. Ich dominacja nie powinna być zaskoczeniem, gdyż ten typ należy dziś do jednej z najbardziej produktywnych kategorii onimicznych. Liczba chrematonimów zresztą stale rośnie w miarę rozwoju przemysłowego i postępu cywilizacyjnego. Przykładem obrazującym to zjawisko jest rozwój różnego typu stowarzyszeń. Godne odnotowania jest w tym wypadku to, że założyciele, tworząc nazwy dla 
swoich organizacji, dość często korzystają z tradycyjnych środków nazewniczych. Odwołują się więc m.in. do leksyki związanej z regionem. Te zabiegi nominacyjne mają z reguły również i głębsze uzasadnienie, czego wyrazem są informacje formułowane w celach statutowych poszczególnych stowarzyszeń. Funkcjonowanie tego typu organizacji jest wyraźnym sygnałem kształtowania się tożsamości lokalnych, a ich nazwy stają się świadectwem tych procesów. Podobnie jak i w przypadku nazw z członem Łużyce, wiele analizowanych form pochodzi z terenu zarówno Łużyc Dolnych, jak i Górnych. Jedynie antroponimy, urbonimy i niektóre chrematonimy odnotowałam także w pozostałej części kraju. Są to jednak przykłady nazw skonwencjonalizowanych, utworzonych według pewnych schematów.

\section{3. Łużyczanin / Łużyczanka}

Łużyczanin / Łużyczanka to etnonimy odnoszące się do słowiańskiej mniejszości zamieszkującej Łużyce. Spośród ogólnych słowników języka polskiego po raz pierwszy leksemy te notuje tzw. słownik wileński: łużyczanin 'mieszkaniec Łużyc, rodem z Łużyc'21.

Łużyczanin ujawnił się w następujących typach nazw:

a) antroponimach: nick ${ }^{22}$ Łużyczanin (użycie tego typu nazwy z reguły jest związane z określeniem miejsca zamieszkania internauty, w moim przekonaniu świadczy także o wytworzeniu poczucia społecznej tożsamości jednostki);

b) urbonimach: ul. Łużyczan (odnotowana tylko w jednym mieście w Lublinie; nazwa o charakterze konwencjonalnym, utworzona według schematu podobnie jak sąsiednie ulice w tym mieście: Lędzian, Ślężan, Polan);

c) chrematonimach: nazwa pociągu Łużyczanin relacji Węgliniec - Wrocław (odwołanie w nazwie do etnonimu ma głównie charakter lokalizacyjny, wskazuje na środek transportu kursujący na określonej trasie);

Łużyczanka ujawniła się w następujących typach nazw:

a) antroponimach: nick Łużyczanka (użycie tego typu nazwy, tak jak w przypadku Łużyczanina, jest związane przede wszystkim z określeniem miej-

${ }^{21}$ Stownik języka polskiego..., s. 615.

22 Nick to identyfikator w obrębie internetowego kanału komunikacyjnego (J. Grzenia, Komunikacja językowa w Internecie, Warszawa 2006, s. 132). Jego status wśród innych nazw własnych nie jest jeszcze ustalony. Niektórzy badacze sytuują go w sferze pośredniej pomiędzy płaszczyzną apelatywną a antroponimiczną (np. A. Naruszewicz-Duchlińska, Pseudonimy internetowe (nicknames) jako forma autoreklamy, „Prace Językoznawcze” 2003, z. 5, s. 86). W związku z tym, że jest on sposobem identyfikacji człowieka, można go uznać za pewien rodzaj nazwy osobowej. 
sca zamieszkania internauty, ale świadczy także o zaawansowaniu procesów tożsamościowych);

b) chrematonimach:

- nazwa lokali gastronomicznych, np.: baru w Zgorzelcu oraz restauracji w Poznaniu i w Kraszewicach (powstanie tego typu nazw nie jest motywowane jedynie względami lokalizacyjnymi, ale przynosi także dodatkowe informacje, np. związane z rodzajem kuchni);

- nazwa klubu sportowego Łużyczanka w Lipinkach Łużyckich i Kuźnicy Grabowskiej (odwołanie w nazwie do etnonimu ma głównie charakter lokalizacyjny, wskazuje na miejsce działalności klubu na określonym terenie);

- nazwa zespołu śpiewaczego Gubińskie Łużyczanki (nazwa wskazuje na obszar działalności, a także prezentowaną przez grupę tematykę i charakter podejmowanych działań).

Jak wynika z powyższego zestawienia, analizowane etnonimy nie stanowią zbyt produktywnej bazy. Nie utworzono z nimi wielu nowych onimów. Zwraca jednak uwagę ich różnorodność. Głównym motywem przeniesienia tych etnonimów na inne nazwy były przede wszystkim względy lokalizacyjne.

Onimy z członami Łużyce, tużycki i Łużyczanin / Łu̇̇yczanka powstały w procesie komunikacji w obrębie określonej wspólnoty głównie jako wynik społecznej potrzeby wyróżnienia poszczególnych obiektów, a także określenia ich położenia. Wyznaczenie przestrzeni jest jednak rzeczą istotną również ze względu na kształtowanie tożsamości mieszkańców poszczególnych regionów. Przynależność do jakiegoś miejsca buduje bowiem pewne interpretacje świata, tworzy więzi społeczne, poczucie wspólnotowości. Nazwy stają się w tym wypadku świadectwem tych procesów. Ważną rolę w tworzeniu analizowanych onimów odegrały także inne czynniki, np. sympatia i zainteresowanie dla mieszkańców Łużyc - ludzi, którzy od wielu lat z pietyzmem pielęgnują swoją kulturę, język, obyczaje, którym mimo niesprzyjających warunków przez tyle stuleci udało się zachować swoją tożsamość. Stanowią oni właściwie fenomen w dziejach Europy, godny naszej refleksji. W przypadku onimów o charakterze pamiątkowym jednym z głównych motywów przeniesienia nazwy na inny obiekt stają się właśnie owe dodatkowe cechy konotacyjne i emocjonalne.

Podejmując temat tego artykułu, zastanawiałam się m.in. nad tym, czy fakt sąsiedztwa z Łużycami (a właściwie nawet historycznej przynależności do nich części naszego kraju) wpłynął na liczbę i różnorodność onimów motywowanych analizowanymi formami. Okazało się, że tak. Zgromadzony materiał badawczy jest bardzo bogaty. W niniejszym artykule zaprezentowano tylko przykłady ilustrujące omawiane typy. W dodatku większość przywołanych egzemplifikacji pochodzi z terenu Polski południowo-zachodniej. Nadanie 
tego typu nazw można więc uznać za świadectwo wysokiej rangi Łużyc i tego, że są nam po prostu bliskie. Zresztą postawa Łużyczan od dawna znajdowała i pewnie znajdować jeszcze będzie życzliwy oddźwięk wśród nie tylko najbliższych sąsiadów.

\section{Iwona Żuraszek-Ryś}

\section{Are We in Close Relationship with Lusatia? About the Names Including the Words Łużyce, tużycki and Łużyczanin / Łużyczanka in Modern Polish}

Lusatia is a phenomenon in the history of Europe. For many centuries its inhabitants bravely struggled against the German element, preserving their identity. Such conduct has earned them our admiration. Does this admiration find reflection in the Polish language, for instance in the proper names used today? This article makes an attempt at answering this question. Special attention has been paid to the onyms including the words Łużyce/Lusatia, tużycki/Lusatian, Łużyczanin/Łużyczanka/male or female inhabitant of Lusatia, excerpted from the Internet with the use of Google browser. Their analysis shows which factors also played an important role in the formation of such names, i.e., sympathy and interest in the inhabitants of Lusatia - the people who have been cultivating their culture, language and customs for many years and who, because of their conduct, are worthy of our reflection.

KEYwORDs: onomastics, Lusatia, anthroponyms, chrematonyms, toponyms, microtoponyms, urbanonyms.

dr Iwona Żuraszek-Ryś - adiunkt w Instytucie Filologii Polskiej Uniwersytetu Zielonogórskiego; zainteresowania badawcze: onomastyka (zwłaszcza toponimia powiatu zielonogórskiego), onomazjologia i historia języka polskiego. 